\title{
Assessment sustainable tourism: a literature review composite indicator
}

\author{
Ratna Purwaningsih, Febrina Agusti*, Susatyo Nugroho Widyo Pranomo, Aries Susanty, \\ Bambang Purwanggono \\ Industrial Engineering Department, Faculty of Engineering, Diponegoro University, Jl. Prof. Soedarto, \\ SH, Kampus Undip Tembalang, Semarang, Indonesia 50275
}

\begin{abstract}
Indicators are very important in the assessment to see the success of the sustainable tourism model. There is still little research involving stakeholders for the determination of sustainable tourism assessment indicators. This study tries to produce a more specific grouping of sustainable tourism assessment indicators was carried out. The literature review study was conducted in 31 indexed international journals uploaded online in the 2010-2020 range. The keyword used for sustainable tourism assessment is an indicator of sustainable tourism assessment. The results of the analysis study, indicators used in the assessment of sustainable tourism obtained as many as 75 indicators (22 economic; 24 social; 29 environmental) with 6 levels of stakeholders which have to validation for future research.
\end{abstract}

\section{Introduction}

In recent years, the emergence of tourism has grown rapidly and attracted a lot of attention. Tourism as an economic activity with a positive impact on improving the well-being of citizens $[1,2]$, job creation, and economic growth [3,4], become the primary objective of many economic sectors $[5,6]$. On the other hand, the concentration of tourism in a geographical region can lead to the exploitation of natural resources and the risk of damage [7]. It is important to balance the needs for economic growth and the exploitation of regional natural resources [8,9], maintain quality of life and development [9, 10, 11]. More specifically in, a social aspect which: defined through assessing the level of satisfaction, social well-being, and stakeholder relations; an economic aspect which: linked to the economic benefits to all stakeholder, employment, income-earning and profitability [4]; environmental aspect: which represented by the intensity of natural resource use, recycling/reuse, pollution, and land used $[3,12,13]$. Management of all resources in such a way that economic and social needs can be fulfilled while maintaining the environment (ecological and biodiversity) which is referred to as sustainable tourism [2, 14, 15]. Sustainable tourism requires awareness that has a low impact on nature and consideration of the support of all stakeholders [16].

\footnotetext{
*Corresponding author: febrinaagusti@gmail.com
} 
The success of a sustainable tourism model requires the use of appropriate measurement tools to quantify the level of tourism sustainability and to grade their evolution over time [17]. This requires complex indicators, autonomous organizations, and networks. Indicators function as a measuring stick by which firms can evaluate how they are accomplishing explicit goals [2]. In tourism planning to sustainable, the importance of meeting stakeholder needs is well recognized [2]. Most research has focused on monitoring economic, social, and environmental indicators or indicators for sustainable tourism in the region without considering their integration between indicators or elements with autonomous or network.

This article, suggest a framework as a "measurement model" of the sustainable tourism to support the compile and collect of indicator involving six levels stakeholder (tourist, resident, tourism, government, tourism management institution, non-government organization) and three dimensions (economic, social, environment).

\section{Sustainable Tourism}

In recent decades, the concept of sustainability has been used in various sectors with different scientific approaches. The paradigm of sustainability is a complex system, integrating economic, social, and environmental. Based on the publication of the Brundtland report in 1987, sustainable development received wide recognition in the world. This report defines sustainable development as "development that meets current needs without reducing the ability to meet of the future generations" [18]. This report underlines two main concepts that are related: the concept of "needs", prioritizing overcoming global poverty: and the concept of "limitations" that are applied to technology countries and can process the environment to meet current and future needs. Later, with the pressure of the environment, sustainability spread to many industries and lead to the emergence of sustainable tourism [19]. Sustainable tourism is hereby reduced to maintaining a 'natural' balance as a measured region towards a strategy that can be applied as an economic trade-off between current use and future needs $[2]$.

Sustainable development has three fundamental pillars known as the triple bottom line (TBL) with their respective roles. The triple bottom line approach (TBL) is a comprehensive approach to achieving sustainability (integrating economic, social, and environmental into business activities) [17]. TBL is planning, reporting, and decision-making framework for achieving sustainable development in the private and public sector organizations. TBL adopt the standards of performance of economic activities, but also social and environmental activities [20]. Some benefits from the application of TBL: increasing market position; cost savings; stakeholder relations; increase strategic decision-making; and the benefits of the wider community [17], market positioning, strategy decision making, and wider destination benefits [2].

The triple bottoms line as pillars of sustainable development is the economic dimension, ecology dimension, and social dimension. In the context of the company, a sustainable economy guarantees that all times sufficient the cash flow is sufficient for the needs of the company and still produces above-average returns to shareholders [21]. Social sustainability means that the human capital of each partner increased and the social capital of the community advances. Ecologically sustainable means that the use or consumption of a natural-resources remain at the level that guarantees its sustainability. TBL reporting as a vehicle for organization or firm to render an account of their activities concerning a wide group of stakeholders and thereby respond to society's growing expectations of transparency [2].

In tourism, influenced by several stakeholders on its sustainability. Stakeholders are viewed as individuals, groups, and organizations such as tourists, tourism businesses, and local communities $[22,23]$. Tourism stakeholders are those individuals and groups who can 
affect, or are affected by, the achievement of tourism development objectives [16]. In terms of sustainable tourism development, various local, national and global stakeholders are involved, including governments, non-government organizations, tourism industry sectors, host communities, tourists, academia, the media [23], owners/investor, competitors, suppliers, the future generation, or business partners [2]. There, five primary stakeholders with whom businesses interact, they are a) government with responsibility for regulating and coordinating; b) local business who derive an indirect income from the operation of commercial enterprises that support the tourism industry; c) non-tourism industry such as manufacturing, mining, and agriculture that operate alongside the tourism industry; d) local community who share their area; e) visitors who make tourism possible [2]. They present a decision tree that identifies twelve stakeholder groups along the axes of support for sustainable development and participation in tourism. Thus, all kinds of stakeholders can express their concern and contribute to the achievement of sustainable development regardless of their involvement in tourism, and vice versa [24]. Information exchange between stakeholders useful to increase sustainable tourism awareness and understanding of the principle of best practice that helps strengthen attitudes, value and actions [2]. Preliminary study by observation and literature study conclude that there are six stakeholders in management of tourism sustainability, Figure 1 presents relationship between stakeholders.

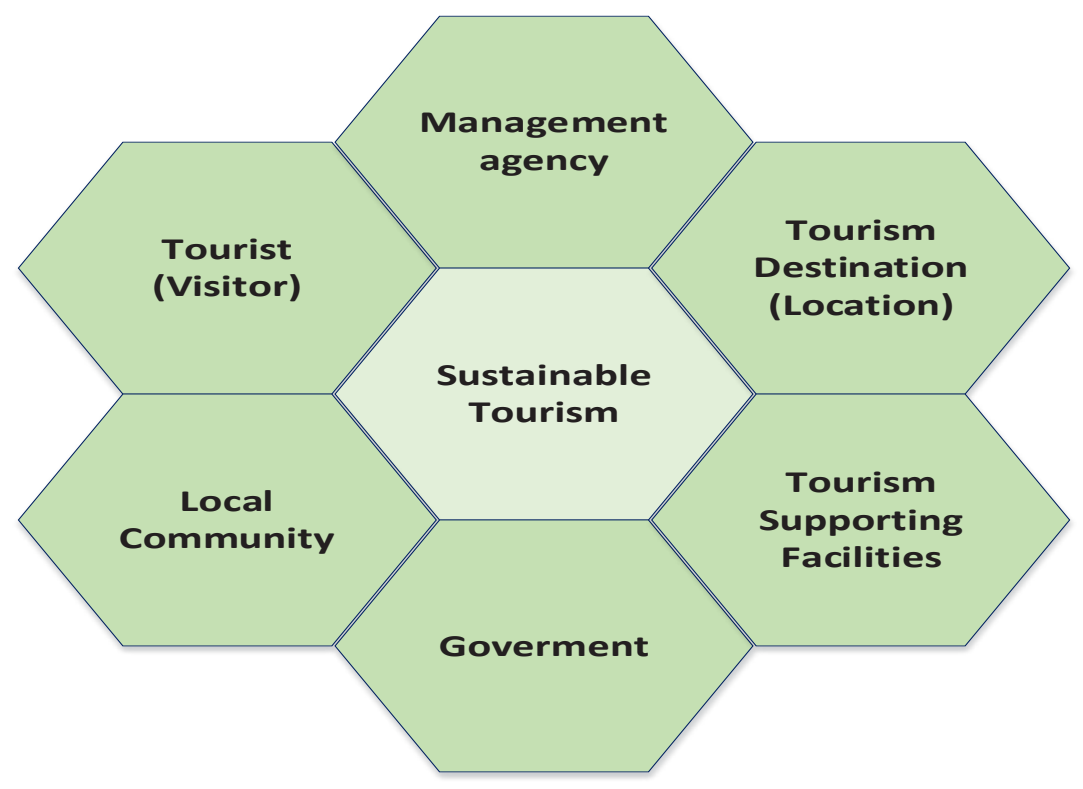

Fig. 1. Relationship between stakeholder and sustainable tourism (Compile by the authors, 2020)

Let's discuss each indicator of sustainable tourism in the model in figure 1 which consist of 6 stakeholders. Tourist or visitors focus on satisfaction and safety, learn about culture, the role in protecting nature, efforts to minimize environmental damage, and energy use. The local community concern on effect of tourism for their economic aspect such as income, availability of markets to promote and sell local product, job vacancy, resident's responsibility and control on pollution and resources consumption. Management agency role on managing the destination, advertising, public relation, provide facility for tourist, water and energy consumption, and location opportunity cost. Government focus on supporting facilities for accommodation, sanitation, public sector investment, increase the tourism sector income, the social and economic effect to surround population, energy consumption, and 
waste management. Tourism supporting facilities is about accommodation establishment (hotel), activities of hotels and restaurants, existing businesses related to tourism. Supporting facilities is not always physical aspect but also the society such as Non-government organizations which represent protecting infrastructure, promote the culture of the region, reduce pollution, protecting the rural environment, and participate in event and event tourism.

\section{Indicator of sustainable tourism}

Indicators are critical to the success of environmental monitoring and reporting as they provide the basis for objective performance assessment [2]. The indicators of sustainable tourism assessment from reputable journal was published in the 2010-2020 range. The journals that have been collected as a source are then filtered by looking at the entire contents of the text. The summary of sustainable tourism indicators sources is presented in Table 1.

Based on five sources of sustainable tourism indicators, the next indicators are grouped by several stages. The first stage, indicators are grouped into 3 dimensions (environmental, economic, and social), grouping is based on the definition of each dimension. Second stage, the results in the first stage are then grouped again based on 6 stakeholders (tourist, resident, tourism, government, tourism management institution, non-government organization), this grouping is based on the definition of each stakeholder.

Table 1. The summary of sustainable tourism indicators sources

\begin{tabular}{|c|c|c|c|}
\hline Author & $\begin{array}{c}\text { The initial number } \\
\text { of indicators }\end{array}$ & Method & Results \\
\hline $\begin{array}{l}\text { Blancas, et } \\
\text { al. [3] }\end{array}$ & $\begin{array}{l}\text { Economic: } 9 \\
\text { Social: } 6 \\
\text { Environmental: } 10\end{array}$ & $\begin{array}{l}\text { Expert } \\
\text { panel- } \\
\text { multidimensi } \\
\text { onal }\end{array}$ & $\begin{array}{l}\text { Indicator for assessment tank and } \\
\text { level sustainable tourism in-country } \\
\text { and rewarding carried out of } \\
\text { management sustainable tourism. }\end{array}$ \\
\hline $\begin{array}{l}\text { McLoughli } \\
\mathrm{n} \text { et al. } \\
{[12]}\end{array}$ & $\begin{array}{l}\text { Economic: } 4 \\
\text { Social: } 5 \\
\text { Environmental: } 7\end{array}$ & Survey & $\begin{array}{l}\text { Provide a new indicator, and } \\
\text { understanding regarding tourism } \\
\text { activities (future tourism planning, } \\
\text { and policy). }\end{array}$ \\
\hline $\begin{array}{l}\text { Ghoochani } \\
\text { et al. [13] }\end{array}$ & $\begin{array}{l}\text { Economic: } 8 \\
\text { Social: } 7 \\
\text { Environmental: } 8 \\
\end{array}$ & $\begin{array}{l}\text { Delphi } \\
\text { method }\end{array}$ & $\begin{array}{l}\text { The indicator measuring sustainable } \\
\text { tourism for management regional } \\
\text { planners and tourism planners. }\end{array}$ \\
\hline $\begin{array}{l}\text { Blancas et } \\
\text { al. [17] }\end{array}$ & $\begin{array}{l}\text { Economic: } 9 \\
\text { Social: } 6 \\
\text { Environmental: } 10\end{array}$ & $\begin{array}{l}\text { DCI- } \\
\text { Dynamic } \\
\text { Composite } \\
\text { indicator }\end{array}$ & $\begin{array}{l}\text { Indicators for the assessment of } \\
\text { sustainable tourism and maintaining } \\
\text { potential indicators. }\end{array}$ \\
\hline $\begin{array}{l}\text { Asmelash } \\
\text { and Kumar } \\
{[25]}\end{array}$ & $\begin{array}{l}\text { Economic: } 3 \\
\text { Social: } 5 \\
\text { Environmental: } 4\end{array}$ & $\begin{array}{l}\text { Delphi } \\
\text { method \& } \\
\text { SEM }\end{array}$ & $\begin{array}{l}\text { Develop and validate indicators for } \\
\text { the assessment of sustainable } \\
\text { tourism that helps to monitor } \\
\text { activity and impact tourism. }\end{array}$ \\
\hline
\end{tabular}

\section{Analysis and discussion}

There are several indicators of sustainable tourism were obtained for economic, social, and environmental dimension. Environmental indicators cover reducing impact, management impact, resource efficiency, use of resources, biodiversity, sanitation, infrastructure, environment protection, climate change, pollution, attitude toward environmental protection. 
Indicator of environmental basically use to conservation and preservation of natural resource, be a "clean" industry, revitalization, and planning control to maintain quality of environment. Specifically, the indicator based on the environmental dimension of the assessment of sustainable tourism shown in Table 2.

Table 2. Indicator based on the environmental dimension of the assessment of sustainable tourism

\begin{tabular}{|c|c|}
\hline Stakeholder & Indicator \\
\hline Tourist & Reducing transport impact [12]; Biological diversity [25] \\
\hline $\begin{array}{l}\text { Local } \\
\text { community }\end{array}$ & Atmospheric pollution $[3,17] ;$ Use of resources $[3,17]$ \\
\hline $\begin{array}{l}\text { Tourism } \\
\text { destination }\end{array}$ & $\begin{array}{l}\text { Protection of the natural ecosystems }[3,17] \text {; Energy management }[3,17] \\
\text { Water management [3,17]; Climate change [12]; Sewage treatment }[12] \\
\text { Physical integrity [25]; Tourism diversity [13]; Protective value of the } \\
\text { wetland [13]; Land-use change [13] }\end{array}$ \\
\hline Government & $\begin{array}{l}\text { Public administrations' expenditure on environmental protection }[3,17] \\
\text { Solid waste management [12]; Water management [12]; Energy usage } \\
\text { [12]; Wastewater management }[3,17] \text {; Management of solid urban waste } \\
\text { [3, 17]; Management of the visual impact of facilities and infrastructure } \\
{[3,17] \text {; Intensity of tourist use }[3,17]}\end{array}$ \\
\hline $\begin{array}{l}\text { Management } \\
\text { Agency }\end{array}$ & Landscape and biodiversity management [12] \\
\hline $\begin{array}{l}\text { Supporting } \\
\text { facilities }\end{array}$ & $\begin{array}{l}\text { Resources efficiency [25]; Environmental purity [25]; Systemic } \\
\text { introducing of destination [13]; Attitude toward environmental protection } \\
\text { [13]; Ambient quality [13]; Biodiversity [13]; Environmental NGOs [13] }\end{array}$ \\
\hline
\end{tabular}

Indicator based on economic affecting to profit tourism in general economic, competitiveness, branding, local prosperity, tourism flow (volume and value at destination, tourism employs, business enterprise related to destination, and sustaining tourist satisfaction. Indicator of economic basically used to stimulates offer livelihood opportunities, support for preservation of local culture though sale handicrafts, and increases governances' tax base. Specifically, the indicator based on the economic dimension of the assessment of sustainable tourism shown in Table 3. 
Table 3. Indicator based on the economic dimension of the assessment of sustainable tourism

\begin{tabular}{|l|l|}
\hline Stakeholder & \multicolumn{1}{c|}{ Indicator } \\
\hline Tourist & Tourism-related transport [3, 17] \\
\hline $\begin{array}{l}\text { Local } \\
\text { community }\end{array}$ & $\begin{array}{l}\text { Tourism flow [12]; Economic viability [25]; Local prosperity [25] } \\
\text { Dependency of income of households around area on tourism [13] }\end{array}$ \\
\hline $\begin{array}{l}\text { Tourism } \\
\text { destination }\end{array}$ & $\begin{array}{l}\text { Sustaining tourist satisfaction [3, 17]; Destination competitiveness [3, } \\
17] \\
\text { Quantity and quality of employment [12]; Employment quality [25] }\end{array}$ \\
\hline Government & $\begin{array}{l}\text { Development control [3, 17]; Gender equality [13]; Hard tourism } \\
\text { infrastructure [13]; Branding [13]; Investment volume [13]; The } \\
\text { diversity of income sources [13]; Willingness to pay [13] }\end{array}$ \\
\hline $\begin{array}{l}\text { Management } \\
\text { Agency }\end{array}$ & $\begin{array}{l}\text { Tourist offers-providing a variety of experiences to visitors [3, 17] } \\
\text { Seasonality of tourism activity [3, 17]; Tourism employment [3, 17] } \\
\text { Tourism enterprise(s) performance [12]; Business enterprises related to } \\
\text { tourism [13] }\end{array}$ \\
\hline $\begin{array}{l}\text { Supporting } \\
\text { facilities }\end{array}$ & Economic benefits of tourism for the business community [3, 17] \\
\hline
\end{tabular}

Indicators of social, cover visitor fulfilment, safety and health, culture richness and exchange, visitor compliance, local interaction, population, psychological, effect on level of well-being in local population, soft infrastructure related to tourism, conservation of cultural heritage, protecting culture and accessibility to inclusion. Social indicator basically used to better understanding and positive social, reaction to facilities or opportunities, improve image and understanding of different culture or communication. Specifically, the indicator based on the social dimension of the assessment of sustainable tourism shown in Table 4.

Table 4. Indicator based on the social dimension of the assessment of sustainable tourism

\begin{tabular}{|l|l|}
\hline Stakeholder & \multicolumn{1}{c|}{ Indicator } \\
\hline Tourist & Health and safety [12]; Visitor fulfilment [29] \\
\hline $\begin{array}{l}\text { Local } \\
\text { community }\end{array}$ & $\begin{array}{l}\text { Community/social impact [12]; Protecting and enhancing cultural } \\
\text { heritage, local identity, cultural assets [12]; Local control [29]; } \\
\text { Community wellbeing [29]; Social capital [13]; Psychological [13]; } \\
\text { Satisfaction of tourism development [13] }\end{array}$ \\
\hline $\begin{array}{l}\text { Tourism } \\
\text { destination }\end{array}$ & $\begin{array}{l}\text { Conservation of cultural heritage [3, 17]; Social equity [25] } \\
\text { Soft infrastructure related to tourism [13] }\end{array}$ \\
\hline & $\begin{array}{l}\text { Safety of the destination [3, 17]; Effects on national population structure } \\
\text { [3, 17]; Social carrying capacity of the destination [3, 17] } \\
\text { Effects on level of well-being in the local population [3, 17]; Cultural } \\
\text { richness [25]; Population [13]; Tourism supply chain [12] }\end{array}$ \\
\hline $\begin{array}{l}\text { Management } \\
\text { Agency }\end{array}$ & $\begin{array}{l}\text { Sociocultural effects of tourism on host community [3, 17] } \\
\text { Gender equality [12]; Inclusion/accessibility [12] }\end{array}$ \\
\hline $\begin{array}{l}\text { Supporting } \\
\text { facilities }\end{array}$ & $\begin{array}{l}\text { Local community participation in the development of tourism [13] } \\
\text { Cultural exchange [13] }\end{array}$ \\
\hline
\end{tabular}

Then, each indicator is grouped based on stakeholders (tourist, resident, tourism, government, tourism management institution, non-government organization) of tourism which most related to the indicators. The stakeholders in the tourism sector commit to ensuring that the quality of life of future generations and the development of long-term 
welfare of tourism are guaranteed and not in trouble. The stakeholders consist of tourists, residents, tourism, government, profit organization, non-government organization. Figure 2 presents the indicators of the assessment of sustainable tourism based on the level of stakeholders.

To test the validity of grouping indicators as a measure of sustainability of each stakeholder, the indicators needs to be tested. The result of the test is the final sustainability measurement model of tourism. Indicator validation can use several methods such as the Delphi method, expert opinion, survey, Dynamic Composite Indicator (DCI), or Structural Equation Modeling (SEM). Beside the right indicators, the method of processing the assessment results also plays an important role in the quality of the measurement results of tourism sustainability. One of the best scaling methods is MDS (Multi-Dimensional Scaling). MDS is a multivariate analysis method which used to process an ordinal or nominal data scale. The results from MDS proved to be more stable than other multivariate analysis methods such as 


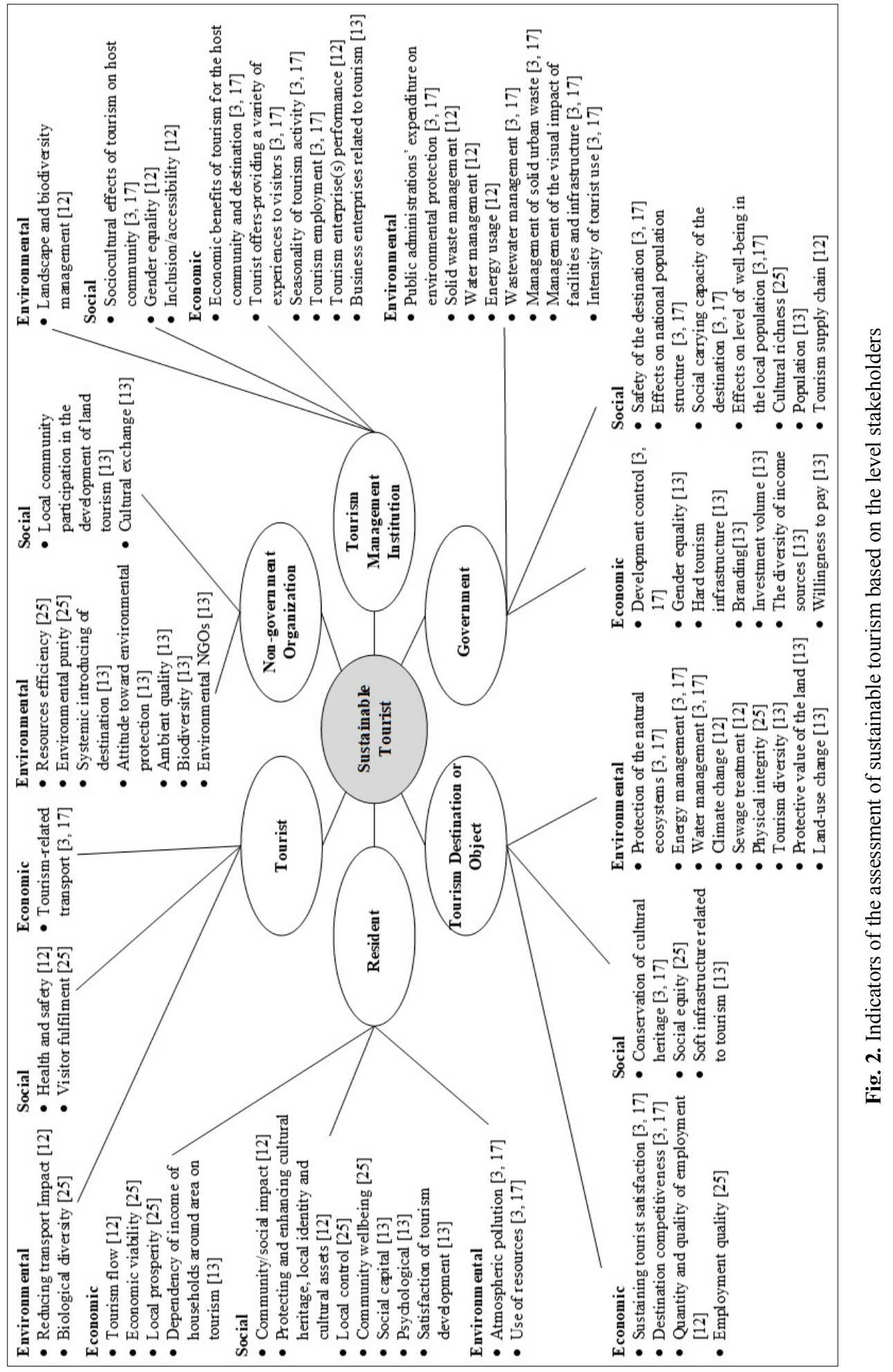


factor analysis and multi-attribute utility theory [26]. Purwaningsih [27, 28] used MDS in Rap-tourism to measure the sustainability index of a tourism destination and define the indicators which need to be improved by leverage factor. MDS is possible to analyze leverage (sensitivity of reducing indicators to sustainability scores). Leverage analysis describes the sensitivity of each indicator to the value of sustainability and used to identify sensitive indicators.

\section{Conclusion}

This article, suggest a framework as a "measurement model" of the sustainable tourism to support the compile and collect of indicator. The indicators used in the assessment of sustainable tourism consist of 6 stakeholders (tourists, residents, tourism, government, tourism management institution, non-government organizations) were obtained as many as 75 indicators ( 22 economic; 24 social; 29 environmental). The indicators must be validated before it can be used for further research such as assessing, rank, positioning tourism, or firm. Indicator validation can use several methods such as the Delphi method, expert opinion, survey, Dynamic Composite Indicator (DCI), or Structural Equation Modeling (SEM).

\section{Acknowledgments}

Authors wishing to acknowledge encouragement from colleagues of Industrial Engineering Department and special work by student team of Magister Program of Industrial Engineering and Management. This research is financially support by DRPM the Ministry of National Education in PDUPT scheme 2020.

\section{References}

[1]. L.J. D’Amore, Tourism Management 9, 2, 151-4 (1988)

[2]. J.J. Liburd and D. Edwards, Understanding the sustainable development of tourism, Oxford: Goodfellow Publishers Limites (2010)

[3]. F.J. Blancas, M.L Oyola, M. Gonzalez, Environmental Impact Assessment Review, 54, 39-54 (2015)

[4]. S. Franzoni, Tourism Management Perspectives, 16, 22-27 (2015)

[5]. F.J. Blancas, M. Gonzalez, M.L. Oyola, F. Perez, Ecological Indicators, 10, 484-492 (2010)

[6]. V. Perez, F. Guerrero, M. Gonzalez, F. Perez, Caballero, Ecological Indicators, 29, 316-324 (2010)

[7]. M. Kostic, M. Lakicevic, S. Milicevic, Economics of Agriculture, 65. 2, 843-857 (2018)

[8]. C. Hunter, Journal of Sustainable Tourism, 3, 155-165 (1995)

[9]. R. Harris, G. Tony, P. Williams, Sustainable tourism: a global perspective, Oxford: Butterworth-Heinemann (2002)

[10]. G. Richard, D. Hall, Tourism \& sustainable community development, New York, NY: Routledge (2000)

[11]. J.D. Silva, V. Fernandes, M. Limont, W.B. Rauen, Journal of Environmental Management 260, 11047 (2020)

[12]. E. McLoughlin, J. Hanrahan, A.M. Duddy, S. Duffy, European Journal of Tourism Research 20, 78-91 (2018)

[13]. O.M. Ghoochani, M. Ghanian, Khosravipour, J. Crotts, Tourism Review (2019)

[14]. A.T. Delgado, F.L. Palomeque, Annals of Tourism Research 49, 122-137 (2014) 
[15]. World Tourism Organization, Tourism: the year 2000 and beyond qualitative aspects. S.I. Madrid: World Tourism Organization (1993)

[16]. T.S. Lee, H.P. Hsieh, Ecological Indicators 67,779-787 (2016)

[17]. F.J. Blancas, M.L. Oyola, M. Gonzalez, R. Caballero, Jurnal of Sustainable Tourism (2016)

[18]. WCED (World Commission of the Environment and Development), Our Common Future, (the Brundtland Report), Oxford: Oxford University Press (1987)

[19]. C.Y. Hsu, G.P. Nyaupane, S.H. Lin, Tourism Management Perspectives 33, 100617 (2020)

[20]. J. Elkington, Environ", Qual. Manag 8, 1 (1998)

[21]. T. Dyllick, K. Hockerts, Business Strategy and the Environment 11, 2, 130-141 (2002)

[22]. R. Baggio, N. Scott, C. Cooper, Tourism Review 65, 4, 51-60 (2010)

[23]. P. E. Murphy, A.E. Murphy, Channel View Publications 6 (2004)

[24]. S. Ellis, L. Sheridan, Tourism Planning \& Development 11, 4, 467-471 (2014)

[25]. A.G. Asmelash, S. Kumar, Tourism Management 71, 67-83 (2019)

[26]. Pitcher T and Preikshot D 2001 Rapfish: A Rapid Appraisal Technique to Evaluate the Sustainability Status of Fisheries (Fisheries Centre Research Reports vol 49) (Canada: Fisheries Centre, University of British Columbia) pp 255-70

[27]. R Purwaningsih, H Santosa, U Khasanah. 2020 IOP Conf. Ser.: Mater. Sci. Eng. 722 012050

[28]. R Purwaningsih, H N Annisa, A Susanty, D D Puspaningrum, AIP Conference Proceedings 2217, 030098 (2020) 